\title{
PERSPEKTIF ISLAM TERHADAP MANAJEMEN PERDAGANGAN SAHAM DI ERA REVOLUSI 4.0
}

\author{
Ahmad Fauzan \\ Dosen Sekolah Tinggi Agama Islam Al-Kamal Sarang Rembang Jawa Tengah \\ Email : ahmadfauzan1985@gmail.com
}

\begin{abstract}
Abstrak
Era revolusi industri 4.0 menyediakan tantangan tersendiri bagi investor atau pelaku bisnis dalam melakukan transkasi. Transaksi saham dengan mempergunakan sistem scriptless trading dimana transaksi dilakukan melalui elektronik baik sistem perdagangan, penyerahan maupun peralihan, sebenarnya merupakan model transkasi yang dijadikan masyarakat atau pebinis di era revolusi industri 4.0. transaksi ini adalah bentuk transaksi modern yang diperbolehkan, karena sudah menjadi kemaslahatan pelaku pasar.

Kata Kunci: era reolusi, saham, investor, Islam
\end{abstract}

\section{Abstract}

The era of industrial revolution 4.0 provides its own challenges for investors or business people in conducting transactions. Stock transactions using a scriptless trading system where transactions are carried out through electronics, both trading, surrender and transition systems, are actually transactions that are made into society or businessmen in the era of industrial revolution 4.0. this transaction is a form of modern transaction that is permissible, because it has become a benefit of market participants.

Keywords: era of revolution, stocks, investors, Islam

\section{PENDAHULUAN}

Masyarakat dunia, termasuk di Indonesia, sedang dihadapkan pada perkembangan industri yang luar biasa. Bukan hanya dalam dunia bisnis teknologi saja yang mengalami revolusi, namun di dunia bisnis yang bersifat diversifikatif pun, perkembangan usaha mengalami hal yang sama, termasuk di era revolusi industri 4.0 Akibat berbagai perkembangan era revolusi industri 4.0 yang demikian cepat ini, berbagai resiko terkadang harus atau terpaksa menimpa masyarakat.

Dapat terbaca, bahwa perkembangan di dunia ekonomi, khususnya perdagangan seiring dengan semakin transparan dan terbukanya hubungan antar personal dan kelembagaan dalam era revolusi industri 4.0, adalah suatu tantangan tersendiri bagi kehidupan dan prospek hukum Islam. Sepertinya ada suatu tuntutan besar, bahwa dalam kondisi apapun, hukum Islam harus mampu memberikan solusinya.

Dalam realitas perkembangan, dapat dipahami bahwa pasar modal merupakan salah satu wahana yang dapat dimanfaatkan untuk memobilisasi dana, baik dari dalam atau luar negeri. Kehadiran pasar modal memperbanyak pilihan sumber dana (khususnya dana jangka panjang) bagi perusahaan.

Keputusan pembelanjaan seperti itu dapat menjadi semakin bervariasi. Implikasi lebih lanjut dari keadaan demikian ini adalah meningkatnya kemampuan perusahaan untuk menemukan struktur modal 
optimal, yaitu struktur modal dengan biaya modal rata-rata tertimbang yang terendah. Dengan demikian tujuan perusahaan untuk mengoptimalkan kekayaan pemilik (shareholder) akan relatif lebih mudah tercapai.

Sementara itu, bagi para investor, pasar modal merupakan wahana yang dapat dimanfaatkan untuk menginvestasikan dananya. Kehadiran pasar modal akan menambah pilihan investasi, sehingga kesempatan untuk mengoptimalkan fungsi utilitas masing-masing investor menjadi semakin besar.

Pasar modal merupakan instrumen ekonomi yang akan memainkan peran yang sangat besar dalam memajukan pertumbuhan perekonomian di masa mendatang. Selain itu pasar modal merupakan wahana investasi bagi masyarakat termasuk pemodal menengah dan kecil, dalam rangka meningkatkan pemerataan, yaitu pemerataan kesempatan untuk memiliki perusahaan publik dengan mendapatkan dividen dan capital gain, sehingga dana masyarakat menjadi produktif (Imaniyati, 2003). Berhubung pengenalan pasar modal di Indonesia selama ini masih terbatas, maka untuk membahasnya sebagai satu pemikiran untuk bahan pertimbangan strategi pengembangannya perlu dikemukakan esensi pasar modal dalam hubungannya dengan fenomena menguatnya transaksi yang menggunakan surat-surat berharga.

\section{PEMBAHASAN}

\section{Perkembangan dan eksistensi Saham dan Scriptless Trading}

Masyarakat pebisnis dimanapun di muka bumi ini paham mengenai saham. Saham diartikan sebagai tanda penyertaan atau pemilikan seseorang atau badan dalam suatu perusahaan atau perseroan terbatas. Wujud saham adalah selembar kertas yang menerangkan bahwa pemilik kertas tersebut adalah pemilik perusahaan yang menerbitkan surat berharga tersebut. Porsi kepemilikan ditentukan oleh seberapa besar penyertaan yang ditanamkan dalam perusahaan tersebut (Darmadji dan Fakhrudin, 2001). Saham sebagai tanda bukti atas kepemilikan terhadap suatu perusahaan, bahkan dikatakan juga sebagai suatu hak terhadap harta kekayaan Perseroan Terbatas karena pada masing-masing akta pendirian Perseroan Terbatas pasti disebutkaan jumlah modal Perseroan yang terbagi dalam jumlah saham-saham. (Hulwati, 2002)

Saham dapat dipahami pula sebagai tanda penyertaan atau penilaian seseorang atau badan dalam perusahan. Namun untuk memperoleh definisi yang lebih lengkap, penyertaan berikut dapat membantu. Selembar saham adalah selembar kertas yang menerangkan bahwa pemilik kertas tersebut adalah pemilik dari suatu perusahaan yang menerbitkan saham tersebut sesuai dengan porsi kepemiliikannya yang tertera pada saham (Widoatmojo, 1996). saham demikian masuk dalam kategori efek penyertaan yaitu efek yang memberikan hak kepada pemegangnya untuk ikut serta dalam equity suatu permasalahan, yakni menjadi pemegang saham dari perusahaan yang bersangkutan. (Fuady, 1996)

Perkembangan dunia saham tidak lepas dari model transaksinya, diantaranya scriptless trading. Dari sudut awal pemahamanan, scriptless 
trading perlu diketahui dari asal katanya, yakni script- naskah tulisan tangan, surat saham. Sementara less-kurang, tanpa, tidak mempunyai. Sedangkan trading adalah proses perdagangan surat-surat berharga, dimana surat berharga berpindah tangan dari penjual kepada pembeli. Jadi trading lebih dititik beratkan ada proses perdagangan di pasar sekunder (Widoatmojo, 1996). Scriptless trading ini merupakan tata cara perdagangan efek tanpa warkat dan diiringi penyelesaian transaksi dengan pemindah bukuan (book entry settlement) yaitu perpindahan efek maupun dana yang melalui mekanisme debit kredit atas suatu rekening efek (securities account). (Darmadji dan Fakhrudin, 2001)

Sistem perdagangan yang aman dan likuid tidak saja terbatas pada saat transaksi efek di bursa akan tetapi meliputi proses kliring dan penjaminan serta penyelesaian dan penyimpanannya. Untuk mencapai tujuan tersebut Undang-Undang No. 8 Tahun 1995 mencoba memperkenalkan sistem perdagangan tanpa sertifkat dan yang mekanismenya mirip sistem pemindah bukuan secara elektronik, yang disebut scriptless trading-book entry settlement (Pramono, 1997). Dalam era revolusi industri 4.0 ini, jelas model demikian dapat dijadikan pilihan strategik berlanjut, khususnya oleh para pelaku bisnis yang punya kegaiahan besar dalam menggenjot dunia usahanya.

\section{Transaksi Menjadi Indikasi}

Kekuatan pasar yang utama terletak pada soal dana dan bagaiman menggunakannya sebagai instrumen transaksi. Di dalam pasar modal dana, yang diperdagangkan adalah instrumen dana jangka pendek, seperti promosi, wesel dan sebagainya. Realisasi pasar modal diselenggarakan dalam bentuk inter bank call money, discount house, dan bentuk lainnya. Di Indonesia pasar modal telah dilaksanakan dalam bentuk inter bank call money. Pengembangannya lebih lanjut dapat diselenggarakan melalui perluasan instrumen yang diperdagangkan dalam pasar tersebut.

Masa atau jangka waktu dalam perdagangan ikut menentukan kualifikasi dan pospek pasar. Di dalam pasar modal, instrumen yang diperdagangkan adalah berjangka panjang, seperti saham dan obligasi. Dua instrumen tersebut mempunyai variasi dan macam sesuai dengan perkembangan keadaan perekonomian serta kompleksitas perusahaan yang bersangkutan. Realisasi Bursa Efek Jakarta ini telah ada sejak sebelum perang dan dalam perkembangannya mengalami pasang surut. Pada saat sekarang ini Bursa Efek di Jakarta merupakan pasar modal. Semula instrumen yang diperdagangkan masih sangat terbatas yaitu saham-saham perusahaan. Saham sendiri, sebagaimana dikatakan oleh Masyfuk Zuhdi termasuk efek atau surat berharga yang dapat diperdagangkan seperti sertifikat dan obligasi, yakni surat berharga sebagai tanda pemegangnya turut memiliki perusahaan yang mengeluarkan surat itu. (Zuhdi, 1988) Pelaksanaan atau penyelenggaraan pasar modal selama ini, dilihat dari segi penerapan aspek hukumnya tanpan terbatas, yaitu hanya dibatasi pada pelaksanaan ketentuan tata cara penawaran efek, serta dipenuhinya syarat-syarat bagi perusahaan calon emiten. 
Sikap atau sepak terjang pelaku di bursa efek ditentukan oleh banyak aspek. Transaksi yang terjadi di bursa, secara umum bukanlah transaksi secara tunai dalam arti bahwa begitu uang dibayarkan seketika itu juga saham diserahkan. Di dalam bahasa bursa, istilah untuk penyelesaian transaksi disebut settlement. Solusi demikian bisa terus mengalami dinamisasi.

Misalnya transaksi itu dapat diketahui di Bursa Efek Jakarta, bahwa pola settlement atau transaksi baru dilakukan empat hari bursa setelah dilakukannya transaksi di bursa atau yang biasa disebut $T+4$. T adalah hari terjadinya transaksi ditambah empat hari bursa. Di dalam settlement tersebut pihak investor sebagai pembeli saham akan memperoleh warkat saham secara fisik tapi dilain pihak ia harus memindahkan rekeningnya ke rekening penjual.

Posisi warkat saham yang dibeli itu dapat disimpan di KSEI. Selanjutnya anggota bursa yang melaksanakan perintah atas pesanan investor melalui Biro Administrasi Efek dapat mendaftarkan dan mengadministrasikan saham tersebut atas nama investor. BEJ menetapkan bahwa batas waktu proses untuk registrasi saham selama-lamanya 7 hari. Apabila investor telah tercatat namanya, investor tersebut telah terdaftar sebagai pemegang saham perusahaan, sehingga ia berhak atas hak-hak yang melekat pada saham tersebut. Hak-hak investor ini yang dipertaruhkan sendiri oleh investor di era reolusi industri 4.0 (Ahsin, 2018)

\section{Manfaat Kepemilikan Saham}

Pihak yang menentukan dalam dunia bisnis, apalagi di era revolusi industri 4.0 adalah investor. Investor yang melakukan pembelian saham, otomatis akan memiliki hak kepemilikan di dalam perusahaan yang menitikberatkannya. Banyak sedikitnya jumlah saham yang dibeli akan menentukan persentase kepemilikan dari investor tersebut. Disinilah kemudian akan dapat ditimang aspek kemanfaatannya di tengah kompetisi era revolusi industri 4.0.

Dalam berbagai studi, dapat diketahui, bahwa secara general ada dua manfaat yang diperoleh bagi pembeli saham, yaitu manfaat ekonomis dan manfaat non ekonomis. Manfaat ekonomis meliputi perolehan dividen dan perolehan capital gain. Dividen merupakan sebagian keuntungan perusahaan yang dibagikan kepada pemegang saham, sedangkan capital gain adalah keuntungan yang diperoleh investor dari hasil jual beli saham, berupa selisih antara nilai jual yang lebih tinggi dibandingkan nilai beli yang lebih rendah.

Era revolusi industri 4.0 menantang secara serius terhadap para investor. Nilai saham akan meningkat sejalan dengan bertambahnya kekayaan perusahaan emiten dalam jangka waktu tertentu. Demikian inilah keuntungan yang diharapkan oleh investor khususnya dalam jangka panjang. Investor membeli saham dan menyimpannya dalam waktu lama, bahkan sampai puluhan tahun. Mereka akan mendapatkan dividen yang dibayarkan oleh perusahaan setiap tahunnya. Pemegang sertifikat saham sebagai surat berharga juga akan mendapatkan manfaat lain, yaitu dapat 
dijaminkan sebagai jaminan tambahan untuk memperoleh kredit dari perbankan.

Manfaat non-ekonomis yang bisa diperoleh oleh pemegang saham adalah kepemilikan hak suara dalam Rapat Umum Pemegang Saham (RUPS) untuk menentukan jalannya perusahaan. Selain manfaat yang bisa diperoleh oleh pemegang saham dari suatu perusahaan, seperti investasi pada umumnya, ada kemungkinan bahwa investor akan mengalami kerugian sebagai risiko yang harus ditanggungnya. Kerugian akan terjadi apabila investor membeli saham pada harga yang lebih tinggi dari pada harga pada saat investor menjual kembali sahamnya. Kerugian ini yang disebut dengan capital loss. Di samping itu, kerugian yang dialami bisa berupa opportunity loss, yaitu selisih suku bunga deposito dibandingkan dengan total hasil yang diperoleh dari total investasi yang dilakukan. Kerugian ini adalah karena suatu keadaan perusahaan emiten dilikuidasi, sedangkan nilai likuidasinya lebih rendah dibandingkan dengan harga beli saham.

Untuk menghindari kemungkinan risiko kerugian, maka investor dapat menghubungi nasihat investasi dan pialang yang dapat memberikan nasihat mengenai investasi yang akan dilakukan. Di samping itu, untuk pemegang saham sebaiknya memprediksikan kedudukan perusahaan emiten apakah mempunyai prospek yang bagus atau tidak. Selain itu kinerja perusahaan, perkembangan industri di mana perusahaan berada, kondisi mikro dan makro ekonomi juga perlu diperhatikan.

Harga saham di bursa efek akan ditentukan oleh kekuatan permintaan dan penawaran. Pada saat permintaan saham meningkat, maka harga saham tersebut akan cenderung meningkat. Sebaliknya, pada saat banyak orang penjual saham, maka harga saham tersebut cenderung akan mengalami penurunan. Era revolusi industri 4.0 yang ditandai dengan kemajuan teknologi industri ini semestinya menjadi kesempatan atau modal stratgis untuk menantang banyak pengusaha untuk menjalakan bisnisnya secara profesionalitas.

Setiap investor mempunyai hak, diantaranya hak atas perlindungan. Bagi investor yang melakukan jual beli di bursa efek akan mendapatkan perlindungan pada saat melakukan transaksi, artinya kalau mereka memberi saham, maka saham-saham tersebut ada dalam kondisi siap diserahkan (good deliver), tidak cacat, baik secara fisik maupun secara hukum. Sebaliknya untuk penjual saham, mereka akan memperoleh hasil penjualannya yang berupa uang (good fund). Jika terjadi kegagalan dalam pelaksanaan good delivery dan good fund, maka investor dapat menuntut denda atas keterlambatan penyerahan saham atau keterlambatan pembayaran uang (Anoraga dan Pakarti, 2001). Saham merupakan efek yang paling umum ditawarkan dalam suatu penawaran umum dan karenanya merupakan instrumen yang paling umum dikenal serta diperdagangkan di pasar modal (bursa). Saham merupakan suatu hak atas bagian dari suatu penyertaan terhadap harta kekayaan perseroan. Oleh karena itu, dalam tiap akta pendirian suatu PT. pasti disebutkan jumlah modal perseroan yang terbagi dalam jumlah saham-saham. 
Jika dianalogikan dengan Al-Syirkah dalam ekonomi Islam, maka pembagian laba atau keuntungan tersebut juga disesuaikan dengan prosentase saham yang dimiliki oleh para investor. Dalam kaitannya dengan pembagian keuntungan ini, pihak perusahaan harus bersifat transparan dan dibicarakan dalam Rapat Umum Pemegang Saham (RUPS), sehingga tidak terjadi kecurangan-kecurangan. Dalam asumsi publik, khususnya kalangan pelaku pasar, kecurangan dalam bertransaksi masih seringkali dianggap sebagai bagian dari pilihan, apalagi ketika menghadapi kondisi-kondisi sulit.

\section{Perspektif Islam}

Mendiskursuskan atau membahas masalah transkasi atau perdagangan saham melalui scriptless trading di bursa efek dalam pendekatan atau perspektif hukum Islam dapatlah diawali dari masalah kedudukan hukum perdagangan saham itu sendiri. Hukum Islam secara umum memperbolehkan jual beli atau transaksi saham.

Saham dapat dianalogikan sebagai benda, barang, atau sesuatu yang dijadikan sebagai obyek transaksi. Saham, merupakan surat berharga sebagai tanda bukti bahwa pemegangnya turut serta dalam permodalan suatu usaha seperti PT. dan lain sebagainya. Kurs saham dapat berubah-ubah bergantung kepada maju mundurnya perusahanperusahaan yang bersangkutan dan situasi ekonomi pada umumnya. Karena itu, pemegang saham bisa mendapatkan untung dan bisa pula mengalami kerugian (Zuhdi, 1988). Antara keuntungan dan kerugian dalam dunia usaha adalah hal yang wajar sebagai resiko bisnis. Namun pada prinsipnya, transaksi saham ini menjadi jenis transaksi modern, apalagi di era revolusi industri 4.0, yang memang bisa memosisikan masalah saham sebagai instrumen istimewa bertraksaksi dengan menggunakan teknologi.

Saham adalah surat berharga yang pada dasarnya mempunyai kekuatan hukum untuk menunjukkan eksistensi nilai ekonomi atau nilai finansial. Husein Syahatah dan Atiyah Fayyād menyebutkan bahwa surat berharga adalah dokumen untuk menetapkan adanya hak kepemilikan dalam suatu proyek atau hutang atas hal itu. (Syahatah dan Fayyad, 2004)

Nash yang terang tentang hal ini dalam Al-Qur'ān dan Hadīs tidak dijumpai. Namun demikian jual beli saham tidak bertentangan dengan hukum Islam. Akan tetapi, perlu dicatat bahwa kebolehan jual beli saham terebut hanya sebatas saham-saham yang bidang usahanya tidak bertentangan dengan Syarīat Islam (ketentuan hukum Islam), misalnya perusahaan yang bergerak dalam memproduksi makanan halal.

Sedangkan perusahaan-perusahaan yang bidang usahanya bertentangan dengan syarīat Islam (seperti perusahaan yang memproduksi minuman keras dan makanan haram lainnya), maka jual beli sahamnya bertentangan dengan kaidah hukum Islam.

Oleh karena itu, bagi seorang muslim yang ingin membeli saham suatu perusahaan, terlebih dahulu harus mengadakan penyelidikan yang seksama tentang bidang usaha dari perusahaan yang menawarkan saham tersebut. Penyelidikan ini diperlukan sebagai upaya penjajakan sebelum memberikan kredibilitas kepada mitra usaha. 
Perlu ditambahkan bahwa pendapat pakar Hukum Islam Abdurrahman Isa, menyatakan jual beli saham dibolehkan oleh agama termasuk saham-saham yang dikeluarkan oleh bank, sekalipun sebagian besar kegiatan bank itu untuk kegiatan perkreditan dengan sistem bunga, karena umat Islam dewasa ini dalam keadaan terpaksa (darurat). (Lubis, 1999)

Kedudukan transksi saham sebagai obyek telah jelas, yaitu diperbolehkan bagi pelaku bisnisnya secara umum. Mengenai prinsipprinsip yang terumus dalam hukum Islam seperti kejujuran, tidak adanya penipuan, dan tidak adanya kecurangan merupakan prinsip yang dapat digunakan sebagai tolok ukur terhadap cara-cara yang digunakan dalam bertraksaksi.

Disebutkan dalam Hadis: "Bekerja seseorang itu dengan tangannya dan setiap jual beli yang baik, ialah yang tidak mengandung penipuan dan pengkhianatan" (HR. Ahmad dan Hākim).

Berdasakan sabda Nbai Muhammad tersebut menunjukkan bahwa dalam hukum Islam, jual beli yang baik menjadi pijakan hukum mubah. Sedangkan jual beli yang baik adalah jual beli yang mengikuti prinsip-prinsip transkasi yang benar, yaitu tidak dilakukan dengan cara penipuan dan pengkhianatan.

Suatu realitas di dunia perdagangan, bahwa seringkali praktik curang masih mewarnai dunia bisnis. Penipuan dan pengkhianatan dapat disebut sebagai bentuk penyimpangan bisnis (abus of bussines), karena bisa dipastikan akan ada pihak lain seperti mitra bisnis yang dirugikan. Begitu pengkhianatan dan kecurangan dilakukan, maka ada hak orang lain yang langsung maupun tidak langsung menjadi hilang atau rusak (fasad).

Scriptless trading merupakan salah satu cara yang bisa digunakan untuk melakukan transkasi saham. Bentuk scriptless trading ini merupakan tata cara perdagangan efek tanpa warkat dan diiringi penyelesaian transaksi dengan pemindah bukuan (book entry settlement) yaitu perpindahan efek maupun dana yang melalui mekanisme debit kredit atas suatu rekening efek (securities account)..(Darmadji dan Fakbruddin, 2001)

Mekanisme tersebut dilakukan dengan menggunakan teknologi elektronika yang sudah diatur sedemikian rupa untuk memperlancar kegiatan perdagangan, khususnya menyangkut kemasalahatan bertranaksi seperti meraih keuntungan, kepercayaan dalam berbisnis, dan akuntabilitasnya.

Dalam hubungannya dengan konteks kemaslahatan di pasar modal perubahan paradigma yang demikian terlihat dengan munculnya fenomena baru dalam bertransaksi efek dapat disikapi sebagai dinamika di dalam hukum Islam. Efek fenomena baru tersebut biasa dikenal dengan istilah scriptless trading, yang dalam Bahasa Indonesia lazim diterjemahkan sebagai perdagangan efek tanpa warkat atau tanpa sertifikat.

Menyikapi cara bertransaksi dengan fenomena baru tersebut (scriptless trading), hukum Islam menilainya sebagai transaksi yang caranya diperbolehkan dengan syarat cara yang digunakan ini merupakan hasil kesepakatan, wujud akad, dan dilakukan dengan memegang teguh amanatnya. Scriptless trading adalah salah satu bentuk modifikasi sistem 
bertraksaksi, yang dapat dianalogikan dengan bentuk lain dari pembukuan modern.

Mengenai dikembalikannya kepada kesepakatan dalam bertransaksi itu, Allāh SWT berfirman: "hai orang-orang yang beriman, patuhilah akadakad (perjanjian-perjanjian) itu” (QS. Al-Māidah: 1). Berdasarkan ayat ini setidaknya menunjukkan, bahwa setiap orang yang beriman, yang sudah membuat perikatan atau perjanjian dituntut untuk mematuhi, tidak ingkar janji, tidak curang, dan tidak menipu, atau keluar dari perjanjian yang semula sudah disepakatinya.

Realisasi pelaksanan penyelesaian transaksi atau perdagangan saham dengan mempergunakan sistem scriptless trading dimana transaksi dilakukan melalui elektronik baik sistem perdagangan, penyerahan maupun peralihan, dengan kata lain tidak ada transfer fisik, sebagai bukti telah berlangsungnya transaksi dapat dilihat melalui rekening efek. Cara perdagangan seperti ini tidak menjadi persoalan (diperbolehkan), karena sistem perdagangan ini telah dicatat dengan alat elektronik. Hal ini dipotong dengan firman Allāh: "Hai orang-orang yang beriman, apabila kamu bermu'amalah (jual beli) tidak secara tunai untuk waktu yang ditentukan, hendaklah kamu menuliskan. Dan hendaklah penulis diantara kamu menuliskannya dengan benar" (Al-Baqarah: 282).

Pencatataan atau penulisan (pembukuan) sebagaimana tertuang dalam ayat tersebut menjadi salah satu unsur penting di dalam menentukan kualitas perjanjian, yang tentu saja juga berlaku di dalam transaksi saham di bursa efek. Transaksi saham jelas dilakukan dengan adanya kesepakatan dan proses pembukuan yang modern, yang sesuai dengan kondisi alat transaksi yang sudah serba modern. Institusi seperti bursa efek merupakan institusi yang menjembatani terjadinya kompetisi antar pelaku pasar dengan cara-cara yang benar dan bertanggungjawab, khususnya dalam menjaga kemaslahatan kelangsungan dan prospek pasar modern ini.

Pendokumentasian atau penulisan suatu perjanjian jual-beli dalam surat, akte, dan sejenisnya merupakan bentuk cara yang digunakan untuk melancarkan, menjamin, dan membenarkannya. Transaksi saham adalah bentuk bisnis modern, yang lebih praktis, yang tentu saja cara-cara yang digunakan juga sesuai dengan zamannya, yakni cara-cara modern. Cara melalui scriptless trading adalah cara modern, yang sebenarnya juga ditujukan untuk kemaslahatan penjual dan pembeli.

Cara modern dalam bentuk scriptless trading adalah produk teknologi yang mengikuti perkembangan bisnis modern pula. Perkembangan dunia bisnis yang sangat pesat telah mendorong masingmasing pelaku bisnis untuk melakukan adaptasi. Kalau adaptasi ini tidak diikuti, dikhawatirkan justru akan merugikan pelaku bisnis atau menjadikan pelaku bisnis gagal memperoleh keuntungan besar. Jika kondisi ini yang terjadi, maka bukan tidak mungkin pelaku bisnis ditimpa problem yang lebih besar, dan gagal merebut peluang lebih baik, yang dampak negatifnya mempengaruhi relasi-relasi lainnya.

Kalau soal kemungkinan dengan cara melalui scriptless trading akan membuka peluang terjadinya praktik penipuan dan pengkhianatan dalam 
transaksi saham, maka kemungkinan itu juga berlaku pada setiap bentuk transkasi di luar transaksi saham. Praktik penipuan sudah seringkali terjadi dalam dunia bisnis dan sudah banyak kerugian ditimbulkannya. Penipuan inilah yang dalam etika berbisnis dilarang kerasa dalam Islam. Islam tidak memprbolehkan cara curang untuk meraih keuntungan. (Mudzafar, 2015)

Status mengenai transkasi saham melalui scriptless trading di pasar modal yang berpijak pada tujuan dan prinsip moral hukumnya inilah yang sangat mendasar dalam menentukan kondisi dunia perdagangan. Besarnya perhatian hukum Islam terhadap masalah bisnis ini dapat dibaca melalui sabda Nabi Muhammad yang melarang perbuatan curang atau menjalankan bisnis dengan cara-cara yang unfair. Disebutkan dalam Hadis: "bekerja seseorang itu dengan tangannya dan setiap jual beli yang baik, ialah yang tidak mengandung penipuan dan pengkhianatan" (HR Ahmad dan Hakim).dari sabda Nabi ini dapat digunakan sebagai pedoman etik berbisnis, bahwa di era apapun, termasuk era revolusi industri 4.0 sekalipun, etika berbisnis harus yang dikedepankan.

\section{KESIMPULAN}

Era revolusi industri 4.0 menyediakan tantangan tersendiri bagi investor atau pelaku bisnis dalam melakukan transkasi. Transaksi saham dengan mempergunakan sistem scriptless trading dimana transaksi dilakukan melalui elektronik baik sistem perdagangan, penyerahan maupun peralihan, sebenarnya merupaka model transkasi yang dijadikan masyarakat atau pebinis di era revolusi industri 4.0. transaksi ini adalah bentuk transaksi modern yang diperbolehkan, karena sudah menjadi kemaslahatan pelaku pasar.

Scriptless trading itu merupakan tata cara perdagangan efek tanpa warkat dan diiringi penyelesaian transaksi dengan pemindah bukuan yaitu perpindahan efek maupun dana yang melalui mekanisme debit kredit atas suatu rekening efek. Transaksi ini tidak terlarang dalam ajaran Islam, karena teknologi hanya sebagai alat yang memperlancar perdagangan saham. Meskipun demikian prinsip bisnis dalam kacamata Islam tetap mengikat, bahwa setiap orang yang beriman, yang sudah membuat perikatan atau perjanjian dituntut untuk mematuhi, tidak boleh ingkar janji, tidak curang, dan tidak menipu, atau keluar dari perjanjian yang semula sudah disepakatinya sebagai kebenaran.

\section{DAFTAR PUSTAKA}

Ahsin, Malaway, 2018, Ujian Pebisnis Era Revolusi Industri 4.0, Jakarta: LP3KI.

Anoraga, dan Pakarti, Piji, 2001, Pengantar Pasar Modal, Jakarta: Rieneka Cipta.

Darmadji, Tjiptono, dan Fakhrudin, Hendy M., 2001, Pasar Modal di Indonesia dan Pendekatan Tanya Jawab. Jakarta: Salemba Empat. Fuady, Munir, 1996, Pasar Modal Modern, Banung: Citra Aditya Bakti. Hasan, Muhammad Tholhah, 2000, Prospek Islam Dalam Menghadapi Tantangan Zaman, Jakarta: Lantabora Press. 
Hulwati, 1999, Transaksi Saham di Pasar Modal (Perspektif Hukum Ekonomi Islam), Jakarta.

Imaniyati, Neni Sri, 2003, Hukum Ekonomi dan Ekonomi Islam, Jakarta: Citra Adtiya Bhakti.

Lubis, Suhrawardi K. 1999, Hukum Ekonomi Islam, Jakarta

Mudzafar, Damin, 2015, Bisnis dalam Etika Islam, Banding: SimaChahaya.

Pramono, Nindyo, 1997, Hukum Pasar Modal di Indonesia, Bandung: Citra Aditya Bakti

Sitompul, Asril, Pasar Modal, Penawaran Umum dan Permasalahannya, Bandung: Citra Aditya Bhakti.

Syahatah, Husein dan Fayyad, Athiyyah, 2004, Bursa Efek-Tuntunan Islam Dalam Transaksi di Pasar Modal, Jakarta: Pustaka Progresif.

Widoatmojo, Sawidji, 1996, Cara Sehat Investasi di Pasar Modal. Jakarta: Jurnalindo Aksara Grafika.

Zuhdi, Masyfuk, 1988, Masailul Fiqhiyah, Jakarta: CV Haji Masagung. 